\title{
PANDEMI COVID-19 DAN PEACEFUL RISE TIONGKOK: BELT AND ROAD INITIATIVE
}

Fuad Azmi, Gilang Nuralam, R.M.T. Nurhasan Affandi, Windy Dermawan

\begin{abstract}
This paper analyzes the impact caused by the COVID-19 pandemic on the Belt and Road Initiative which is part of the Peaceful Rise policy implemented by the Chinese State by conducting literature studies using the perspective of neoliberalism as the basis for analysis. The literature we use in this research ranges from books, journals, to electronic media with qualitative and quantitative data. By considering the findings obtained, we reveal the impact of this pandemic on the factors that influence the progress of China's Peaceful Rise policy and more specifically the Belt and Road Initiative policy. The conclusion we got was that the Belt and Road Initiative, which is China's effort to apply the principle of neoliberalism, has experienced problems in allocating funds, as well as a reduction in the overall workforce.
\end{abstract}

Keywords: Belt and Road Initiative; COVID-19; Neoliberalism; Peaceful Rise

\section{PENDAHULUAN}

Tiongkok merupakan negara yang dianggap mengalami kebangkitan luar biasa dalam abad ke-21. Padahal sebelumnya menurut beberapa ahli pada abad ke-19, Tiongkok merupakan daerah yang stagnan, terbelakang, dan terancam hancur oleh tindakan sembrono para penguasanya (Hobson, 2004). Hal tersebut mengakibatkannya menjadi salah satu target eksploitasi negara - negara seperti Inggris, Jepang, dan negara - negara kuat lainnya. Tidak ada satu pun dari para ahli tersebut yang menganggap bahwa negara tirai bambu tersebut dapat kembali berjaya di dalam ruang lingkup global. 
Prediksi para ahli tersebut terbukti salah, dimana berbeda dengan ekspektasi mereka, Tiongkok kini menjadi salah satu kekuatan terkuat dalam perekonomian dunia. Hal tersebut terjadi akibat beberapa faktor, diantaranya faktor internal yaitu perombakan sistem perekonomian, dan penerapan peaceful rise policy keluar negara tersebut. Penerapan peaceful rise policy ini sendiri berdampak positif terhadap citra Tiongkok di mata dunia internasional.

Walaupun banyak negara yang menganggap Tiongkok secara negatif sebagai negara yang menggunakan dunia internasional sebagai alat untuk mencapai kepentingan negaranya sendiri, namun banyak juga negara seperti negara - negara Afrika seperti Nigeria, Ghana, dan Kenya yang menganggap Tiongkok sebagai pihak yang memberi dampak positif di dunia (Chen, 2014).

Citra Tiongkok sebenarnya telah mengalami perkembangan dari tahun ke tahun di mana bantuan yang ia berikan kepada negara - negara yang ada di dunia menyebabkan makin banyak negara yang kemudian mau ditanami modal oleh Tiongkok dan berakibat pada kekuatan ekonomi Tiongkok yang terus mengalami perkembangan dan pertumbuhan dari tahun ke tahun.

Namun pandangan dunia terhadap Tiongkok mengalami perubahan signifikan ke arah negatif akibat pandemi Covid-19. Pandemi ini mengakibatkan tumbuhnya sentimen negatif dalam tingkat luar biasa yang belum pernah dilihat sebelumnya sejak Tiongkok menjalankan kebijakan untuk menampilkan dirinya sebagai salah satu pilar utama dalam menjaga world order. Hal inilah yang mengakibatkan, permasalahan ini menjadi suatu hal yang menarik untuk dikaji.

\section{Kebijakan 'Peaceful Rise' Tiongkok}


Konsep peaceful rise sendiri merupakan evolusi dari konsep Tiongkok lain yang bernama new security concept (NSC). Konsep NSC ini pertama kali dikenalkan oleh para pemimpin Tiongkok generasi ketiga sebagai konsep keamanan yang cocok untuk diaplikasikan pasca Perang Dingin; lebih tepatnya pada 1997 di mana konsep tersebut pertama kali muncul dalam sebuah perjanjian keamanan besar dengan Rusia dan negaranegara Asia Tengah lainnya. NSC dikonsepsikan oleh analis-analis Tiongkok yang mengambil pelajaran dari runtuhnya Uni Soviet yang mereka percaya sebagai akibat dari fokus Uni Soviet terhadap militernya yang berlebihan, alhasil mengorbankan dimensi ekonomi mereka.

Dilihat sekilas, konsep NSC ini hampir menyerupai konsep keamanan manusia (human security) di mana keduanya memprioritaskan penanganan ancaman non-tradisional seperti kerusakan lingkungan, terorisme, penyelundupan narkoba, migrasi, keamanan energi, wabah penyakit, kemiskinan, dan sebagainya. Persepsi Tiongkok mengenai konsep baru ini terdiri dari enam titik fokus, yakni: menghindari perang dengan negara-negara besar, globalisasi, Amerika Serikat sebagai mitra kerja sama sekaligus pesaing, tantangan keamanan non-tradisional, tidak amannya energi, dan kenaikan Tiongkok. Mereka berargumentasi bahwa di era baru ini, keamanan perlu didasari oleh kepercayaan terhadap satu sama lain serta kesamaan kepentingan. Mereka juga menganggap bahwa pengimplementasian NSC ini beserta tatanan internasional baru yang adil adalah satu-satunya cara untuk memajukan proses pelucutan dan menjamin perdamaian dan keamanan dunia. (Kumar, 2012)

Peaceful rise Tiongkok adalah istilah yang sering digunakan oleh pihak Tiongkok untuk meyakinkan seluruh dunia bahwa kenaikan Tiongkok dalam ranah hubungan internasional tidak akan menimbulkan keburukan atau ancaman pada negara mana pun, tetapi sebaliknya akan menimbulkan kebaikan dan manfaat untuk negara lainnya, terutama negara-negara tetangga Tiongkok. Konsep ini pertama kali dikenalkan 
oleh Zheng Bijian, mantan Wakil Kepala Sekolah Partai Sentral (di mana pejabat-pejabat Partai Komunis Tiongkok dididik sebelum menjabat), pada sebuah pidato dalam Bo'ao Forum for Asia pada 3 November 2003. Konsep ini kemudian diwujudkan menjadi sebuah kebijakan luar negeri resmi oleh Sekretaris-Jenderal Partai Komunis Tiongkok generasi keempat $\mathrm{Hu}$ Jintao serta Perdana Menteri Tiongkok keenam Wen Jiabao. Wen sempat mengutip konsep ini dalam pidatonya sebelum ia mengakhiri kunjungannya ke Amerika Serikat pada 10 Desember 2003 di Universitas Harvard. Selain itu, dalam sebuah konferensi pers pada Maret 2004, Wen menjelaskan lima poin penting dalam peaceful rise Tiongkok, yaitu:

1. Konsep ini akan memanfaatkan perdamaian dunia untuk mempercepat pembangunan Tiongkok dan menjaga perdamaian dunia melalui pembangunan Tiongkok;

2. Konsep ini akan didasari oleh kekuatan Tiongkok sendiri dan kerja keras mandirinya;

3. Konsep ini tidak dapat dicapai tanpa mempertahankan "kebijakan membukakan diri" dan keaktifan dalam perdagangan internasional;

4. Konsep ini perlu melewati beberapa generasi untuk dapat terwujud; dan

5. Konsep ini tidak akan menghalangi atau mengancam negara lain serta tidak akan dicapai dengan mengorbankan negara lain. (Suettinger, 2004)

Meskipun begitu, konsep ini juga sering diganti dengan kata peaceful development karena penggunaan kata rise justru berkesan mengintimidasi secara tersirat (Sujian, 2006). 


\section{Belt Road Initiative}

Belt Road Initiative merupakan suatu strategi pembangunan global yang digadang - gadang oleh Presiden Xi Jinping sebagai suatu sarana untuk memajukan perekonomian Tiongkok beserta 70 negara sahabat di Asia, Eropa, Afrika, bahkan hingga Amerika Selatan. Strategi ini berbentuk pembangunan infrastruktur di wilayah yang digadang - gadang dapat menyaingi Jalur Sutra pada zaman dahulu. Di mana Jalur tersebut pada zaman Dinasti Han merupakan jalur perdagangan besar yang melalui negara - negara Asia Tengah, diantaranya termasuk Kyrgyzstan, Tajikistan, Uzbekistan, Afghanistan, serta Pakistan dan India di daerah Selatan rute, bahkan hingga menuju ke Eropa.

Pada zaman dahulu, Jalur Sutra ini menjadi rute perdagangan yang ramai di mana komoditas dari belahan Barat dunia seperti logam mulia, dan komoditas lainnya bercampur dengan komoditas dari Timur seperti rempah - rempah dan sutra. Banyaknya pengguna dari rute ini mengakibatkan kemajuan ekonomi yang luar biasa bagi negara - negara yang ikut terlibat dalam perdagangan di rute ini, tidak terkecuali Tiongkok. Namun, perdagangan di rute ini mengalami kemunduran drastis akibat invasi dari pasukan Mongolia di Asia Tengah, serta banyaknya perang agama yang menghambat pergerakan komoditas.

Sejarah keberhasilan ekonomi Tiongkok yang diakibatkan oleh Jalur Sutra tersebut yang menyebabkan strategi yang awalnya bernama OBOR (One Belt One Road) ini kemudian diagung-agungkan secara aktif oleh pemerintah Tiongkok sebagai penyambung yang kuat antara Tiongkok dan negara - negara sahabat dalam bidang ekonomi. Di mana rencana ini di sampaikan Xi Jinping pada pidatonya di Universitas Nazarbayev, Kazakhstan pada September 2013. (Xinhua, 2015) Inisiatif ini terdiri dari serangkaian proyek-proyek pembangunan infrastruktur yang memiliki visi sebagai “Jalur Sutra Abad ke-21." Istilah belt mengacu kepada jalur-jalur darat yang akan melintasi negara-negara lokasi Jalur Sutra asli (Asia 
Tengah, Asia Barat, Timur Tengah, dan Eropa) sementara istilah road mengacu kepada jalur-jalur maritim yang sebagian besar terdiri dari Asia Tenggara, Asia Selatan, Timur Tengah, dan Afrika Timur. Inisiatif ini ditargetkan selesai pada tahun 2049 yang berdampingan dengan hari ulang tahun RRC ke-100.

Jalur darat dari inisiatif ini (belt) terdiri dari lima koridor, yaitu: (1) New Eurasian Land Bridge, (2) Koridor Tiongkok-Mongolia-Rusia, (3) Koridor Tiongkok-Asia Tengah-Asia Barat, (4) Koridor TiongkokSemenanjung Indochina, dan (5) Koridor Ekonomi Tiongkok-Pakistan. (Ramasamy, Yeung, Utoktham, \& Duval, 2017) Sementara itu, jalur maritim dari inisiatif ini (road) memiliki empat rute, yaitu: (1) Rute Tiongkok-Asia Tenggara, (2) Rute Tiongkok-Asia Selatan, (3) Rute Timur Tengah dan Afrika Timur, dan (4) Rute Eropa.

Untuk mempermudah jalannya inisiatif ini, Xi Jinping juga menyarankan untuk membentuk sebuah bank baru yang bernama Asian Infrastructure Development Bank (AIIB). AIIB pertama kali dikenalkan pada kunjungan Xi ke parlemen Indonesia pada Oktober 2013. (Xinhua, 2015) Bank ini didirikan untuk mempermudah pengeluaran pinjaman ke negara-negara mitra Belt \& Road Initiative. Tujuan utamanya adalah untuk memenuhi kebutuhan infrastruktur yang terus berkembang di Asia, menghadirkan integrasi regional, mendorong pertumbuhan ekonomi, dan memperbaiki akses publik terhadap layanan sosial. (AIIB, 2017) AIIB kini beranggotakan 78 negara di mana 49 di antaranya merupakan anggota regional di wilayah Asia; sisanya merupakan anggota non-regional yang berada di Eropa dan Afrika.

\section{Neoliberalisme Ekonomi}

Pemikiran neoliberalisme ekonomi saat ini berbasis pada pemikiran liberalisme mengenai pasar bebas, penghilangan batasan-batasan perdagangan, dan campur tangan pemerintah yang minim dalam 
perdagangan. Perbedaan utama bagi liberalisme ekonomi dan neoliberalisme ekonomi merupakan kepercayaan neoliberalisme ekonomi akan pentingnya peran yang dimainkan institusi ekonomi internasional dalam pasar perdagangan dunia, yang jika dibandingkan dengan pemikiran liberalisme ekonomi klasik tidak menganggap bahwa institusi ekonomi internasional merupakan aktor yang memainkan peran signifikan dalam pasar perdagangan dunia. Selain itu, pemikiran neoliberalisme ekonomi juga berargumen bahwa meski negara-negara dan industri-industri yang in efisien dapat menderita dari penerapan pembebasan pergerakan investasi kapital dan tenaga kerja, kekayaan dunia akan semakin naik. Pada akhirnya neoliberalisme ekonomi juga percaya bahwa dengan penerapan pasar bebas, ketidaksetaraan dapat bertumbuh, tetapi bahkan negara-negara paling miskin dapat menjadi lebih baik dengan pertumbuhan ekonomi dalam keseluruhan (Lamy, Masker, Baylis, Owens, \& Smith, 2014, hal. 511).

Neoliberalisme, meski menginginkan pasar yang tidak diatur oleh pemerintah negara manapun, tetap memiliki bentuk-bentuk intervensi legal, institusional, dan kultural oleh negara dalam praktiknya. Bentukbentuk intervensi itu datang dalam reformasi-reformasi legislatif, persetujuan institusional, dan kondisi-kondisi sosial yang memperbolehkan rasionalitas pasar mengenai kewirausahaan kompetitif bekerja dengan efektif (Suzana Sawyer, 2012, hal. 26). Maka dari itu, pada kenyataannya, neoliberalisme ekonomi tidak dapat memisahkan pemerintah negara dari pasar maupun pasar dari pemerintah negara. Neoliberalisme ekonomi memerlukan pemerintah untuk dapat mengikuti keinginannya dan menciptakan aturan-aturan yang menguntungkan pemikiran tersebut. Hal ini dapat dicapai melalui janji-janji akan keuntungan yang dapat diperoleh oleh negara ketika menerapkan kebijakan-kebijakan yang dapat dikatakan menguntungkan negara dan 
pertumbuhan pasar, yang pada dasarnya menguntungkan pemikiran itu sendiri.

\section{Gambar 1.1 Institusi Ekonomi Internasional}

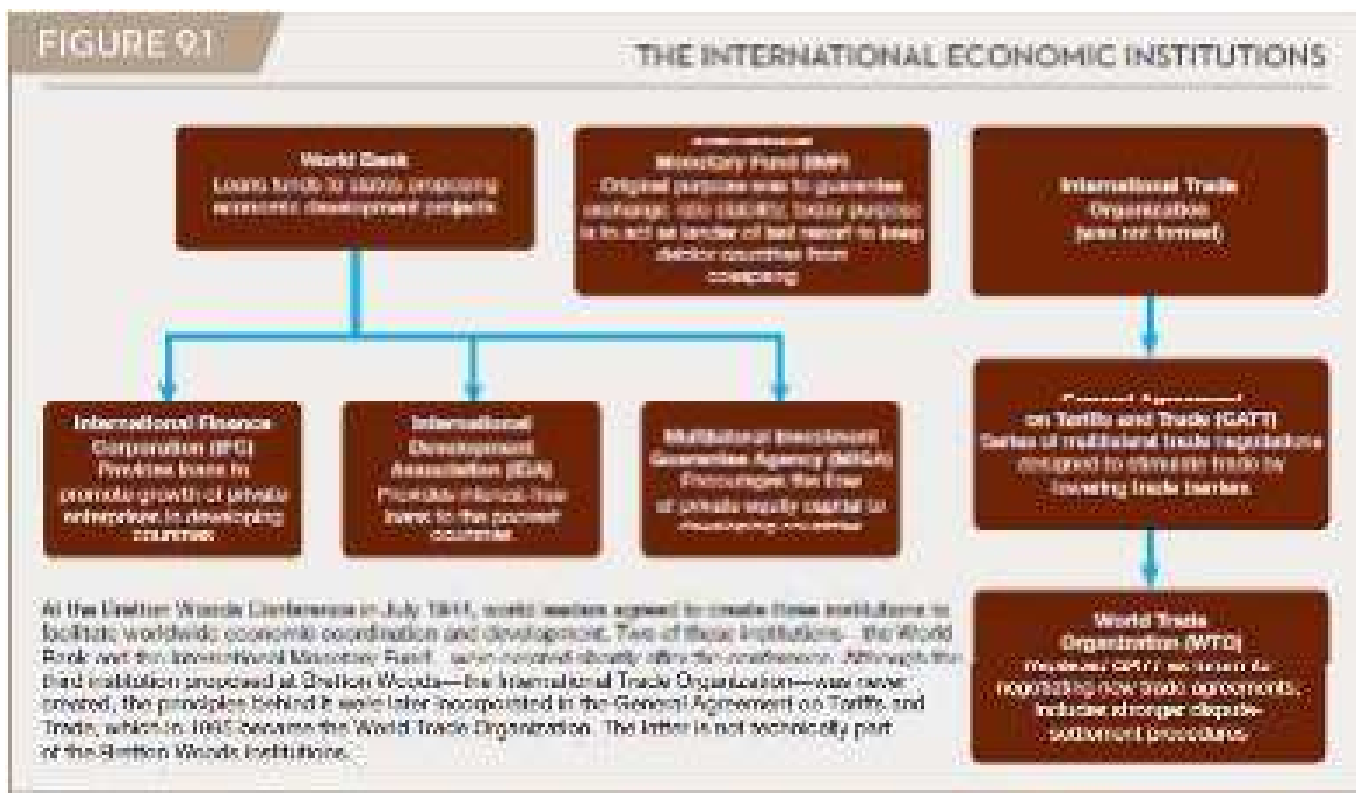

Sumber: Mingst \& Arreguin-Toft, 2017, hal. 322

Institusi-institusi sistem Bretton Woods seperti International Monetary Fund (IMF), World Bank, dan World Trade Organization (WTO) memainkan peran yang signifikan dalam penyebarluasan pemikiran neoliberalisme ekonomi (Mingst \& Arreguin-Toft, 2017, hal. 320). Dari gambar di atas dapat dilihat bahwa sistem Bretton Woods merupakan perwujudan dari usaha pemikiran neoliberalisme ekonomi untuk mempengaruhi pemerintah-pemerintah negara di dunia untuk menciptakan keputusankeputusan yang akan menguntungkan pemikiran tersebut. Tiap-tiap institusi yang berada dalam sistem Bretton Woods memainkan peran yang sebagaimana rupa dapat mendorong pemerintah negara untuk menciptakan keputusan yang diatur oleh institusi tersebut guna mendapatkan keuntungan ekonomi dari institusi tersebut. 


\section{METODE PENELITIAN}

Metode penelitian yang kami gunakan merupakan model kualitatif, dimana tim penulis menggunakan metode ini karena dirasa tepat dalam menganalisis topik ini. Metode model kualitatif ini kami gunakan selain karena sering digunakan dalam penelitian sosial humaniora, namun juga karena kami menganggap metode ini dapat mengungkap penjelasan yang tepat mengenai latar belakang permasalahan yang kami angkat. Tim penulis menganggap fleksibilitas yang dimiliki oleh metode penelitian ini dapat menciptakan suatu pemahaman yang tidak dapat didapatkan melalui metode model kuantitatif.

Pengumpulan data sendiri kami lakukan dengan menggunakan studi literatur baik itu yang berbentuk artikel jurnal, buku, media elektronik, serta sumber - sumber informasi lainnya untuk dapat memahami Peaceful Rise Policy dan lebih spesifiknya Belt and Road Initiative serta dampak yang diakibatkan oleh pandemik COVID-19 terhadap kebijakan tersebut melalui kacamata perspektif Neoliberalisme. Data yang didapatkan kemudian kami gunakan untuk melakukan analisis deskriptif terhadap fenomena ini.

\section{PEMBAHASAN}

\section{Kebijakan 'Peaceful Rise' Tiongkok menurut Neoliberalisme}

Tujuan utama neoliberalisme merupakan 'pengunduran batas-batas negara', dengan mempercayai bahwa kapitalisme pasar yang tidak diatur dapat menghasilkan efisiensi, pertumbuhan, dan kemakmuran yang tersebar luas (Heywood, 2013, hal. 37). Kebijakan 'Peaceful Rise' Tiongkok menunjukkan ciri-ciri keinginan neoliberalisme dengan prinsip utamanya yang menghindari neo merkantilisme dan proteksionisme pasar. Tiongkok, sebagai sebuah negara, tidak akan mengontrol pasar seketat sebelumnya, tetapi juga tidak akan membiarkan pasar tanpa adanya aturan. 
Kebijakan-kebijakan kunci neoliberalisme termasuk privatisasi, pengeluaran publik yang rendah, deregulasi, pemotongan pajak, dan pengurangan ketentuan kesejahteraan (Heywood, 2013, hal. 144). Sebagian dari kebijakan-kebijakan kunci tersebut muncul dalam kebijakan 'peaceful rise' Tiongkok, yang menjadikan kebijakan tersebut condong ke arah keinginan neoliberalisme.

Kesamaan kebijakan 'peaceful rise' Tiongkok dengan keinginan Neoliberalisme berakhir pada negara tidak memiliki kontrol total terhadap kebijakan-kebijakan pasar. Dengan kebijakannya, Tiongkok tetap akan memiliki kontrol terhadap supply dan demand, serta kebijakan-kebijakan yang dapat mempengaruhi pasar, seperti kontrol terhadap tarif. Privatisasi menjadi salah satu kendala yang dihadapi oleh pemerintah Tiongkok ketika melihat kebijakan tersebut dari sisi Neoliberalisme. Setelah tahun 2000, hanya sebagian perusahaan menengah ke bawah diprivatisasi dan menjadi publik. Mayoritas perusahaan Tiongkok masih dipegang dan dikontrol oleh negara, yang merupakan hambatan bagi tercapainya keinginan pasar bebas Neoliberalisme.

Tujuan utama kebijakan tersebut oleh Tiongkok merupakan perkembangan ekonomi yang sesuai dengan globalisasi (Chinese State Council, 2005). Keinginan tersebut dapat mendorong Tiongkok untuk bergerak semakin condong ke ruh Neoliberalisme, yang mana, dengan bertambahnya kompetisi internasional, dapat memaksa pemerintah Tiongkok untuk menderegulasi ekonominya dan mengurangi tingkat pajak dengan harapan menarik investasi dan mencegah TNC-TNC untuk merelokasi ke negara lain. Keinginan Tiongkok untuk mengikuti arus globalisasi dapat menjadi kunci agar kebijakan Tiongkok dapat menjadi kunci bagi Tiongkok untuk mencapai keinginan pasar bebas Neoliberalisme. 
Tiongkok memiliki keuntungan dari populasi besar dan sejumlah sumber daya budaya termasuk seni, sastra, musik, dan filsafat. Oleh karena itu, Tiongkok tidak akan pernah kehabisan partner dagang. Tantangan terbesar bagi Tiongkok adalah kompetitor yang, ketika dibandingkan dengan Tiongkok, memiliki kebijakan pasar yang lebih terbuka yang berpotensi menghilangkan nilai jual pasar Tiongkok. Kebijakan 'peaceful rise' oleh Tiongkok berpotensi menambah nilai jual pasar Tiongkok, dan potensi ini terlihat ketika, pada 2008, Tiongkok menjadi negara ekonomi terbesar kedua setelah Amerika Serikat.

Secara keseluruhan, kebijakan 'peaceful rise' Tiongkok merupakan perwujudan paling nyata dari keinginan Neoliberalisme bagi Tiongkok. Tiongkok telah memiliki kontrol total akan perekonomiannya semenjak Revolusi Komunis Tiongkok. Dengan dicetuskannya kebijakan tersebut, Tiongkok telah menginjakkan langkah pertamanya untuk mengurangi kontrol negaranya atas pasar yang sebelumnya dikuasai total oleh negara. Kebijakan ini berpegang teguh pada prinsip bahwa Tiongkok akan selalu terbuka bagi perdagangan dengan negara-negara lain (Chinese State Council, 2005). Dengan prinsip tersebut, Tiongkok dapat berpotensi melepaskan kontrol negara atas pasar lebih jauh lagi, hal ini memiliki potensi yang besar untuk terwujud dikarenakan keinginan Tiongkok untuk menarik investasi-investasi asing.

\section{Belt \& Road Initiative Dari Perspektif Neoliberalisme}

Inisiatif ini tentunya merupakan perwujudan dari kebijakan peaceful rise yang telah dibahas sebelumnya. BRI merupakan perwujudan dari neoliberalisme di mana tujuan utama yang ingin diraihnya adalah keterbukaan pasar-pasar nasional di seluruh dunia serta percepatan pertumbuhan ekonomi. (Balaam \& Dillman, 2013, hal. 40) Percepatan tersebut dipercaya dapat diraih melalui penyebaran infrastruktur di 
seluruh dunia yang akan memperlancar kegiatan dagang ke seluruh penjuru dunia. Tentu saja tanpa terbukanya pasar-pasar nasional terhadap investasi asing, BRI tidak akan pernah terwujud. Hanya saja, perusahaan-perusahaan yang terlibat dalam proyek-proyek BRI masih mayoritas dimiliki oleh negara dan belum diprivatisasi (seperti China State Railway Group Company, Ltd. yang telah memenangkan lelang untuk membangun jalur kereta kecepatan tinggi Jakarta-Bandung pada 2016). Hal ini tidak seirama dengan skeptisisme neoliberalisme terhadap peran negara yang terlalu besar.

\section{Pengaruh Covid-19 Terhadap Belt Road Initiative dalam Perspektif Neoliberalisme}

Rencana ini merupakan sebuah strategi dengan ruang lingkup yang luar biasa besar yaitu memengaruhi 65\% populasi dunia dan 40\% dari GDP dunia turut menjadi faktor dalam strategi ini. Langkah ini merupakan salah satu contoh usaha Tiongkok dalam menunjukkan posisi Peaceful Rise Policy yang ia tunjukan dalam berbagai kesempatan. Kenyataan bahwa Tiongkok bersedia menanamkan investasi besar besaran pada negara - negara yang menyetujui BRI dan retorika yang sering ia angkat di mana ia menginginkan Tiongkok dan negara - negara sahabat agar dapat maju bersamaan menyebabkan strategi ini menggiurkan bagi negara - negara yang dilintasi oleh strategi ini.

Namun, tidak dapat dipungkiri bahwa munculnya pandemi Covid-19 mempengaruhi kelangsungan strategi ini. Pada awal Januari 2020, ada 2951 proyek pembangunan di seluruh dunia yang dikaitkan dengan strategi BRI seharga 3,87 triliun dolar (Oxford Business Group, 2020). Namun, pandemi skala besar yang terjadi di seluruh dunia mengakibatkan hambatan besar terhadap proyek - proyek tersebut, dimana pandemi menyebabkan perhatian dan pendanaan yang awalnya dialokasikan pada proyek BRI kemudian digeser kepada pendanaan alat - 
alat medis dan sarana kesehatan untuk menangkal pandemi, yang juga menyebabkan negara - negara di dunia kemudian tidak meminjam dana dari Tiongkok untuk proyek BRI karena fokus dalam bidang kesehatan. Hal ini diprediksi oleh beberapa analis menyebabkan kemunduran dalam proyek BRI yang membutuhkan waktu bahkan hingga satu tahun untuk dapat diselesaikan (Elmer, 2020).

Selain itu, masalah besar lainnya yang diakibatkan oleh virus corona terhadap strategi terbesar Tiongkok dalam bidang ekonomi ini bukan hanya ketidakmampuan negara untuk meminjam dana untuk Belt Road Initiative namun juga hilangnya rasa percaya yang dimiliki oleh negara negara yang ada di dunia. Dunia internasional menganggap bahwa Tiongkok telah dengan sengaja menutup-nutupi dampak sebenarnya dari penyakit yang bermula di Wuhan, Tiongkok ini. Selain itu, dalam populasi dunia muncul juga Sinophobia di mana sentimen anti-Tiongkok juga semakin berkembang. Hal tersebut mengakibatkan rusaknya hubungan baik antara Tiongkok dengan negara - negara lain di dunia, dan menyebabkan salah satu aspek penting ekonomi neoliberal yaitu investasi yang dilakukan Tiongkok menjadi semakin sulit.

Kyrgyzstan misalnya, pemerintahan tetangga Tiongkok yang memiliki tingkat pendapat pendapatan per kapita rendah ke menengah ini menerima dengan baik niat Tiongkok yang ingin melakukan investasi ke negara tersebut. Namun, kuatnya sentimen anti Tiongkok sebagian warga Kyrgyzstan yang diperparah dengan Sinophobia yang semakin menguat menyebabkan semakin kuatnya gerakan anti-Tiongkok di negara tersebut yang memuncak pada Februari 2020 dimana hal tersebut menyebabkan gagalnya rencana investasi Tiongkok untuk membuat pusat logistik yang menjadi bagian rencana BRI seharga 275 juta dolar (Putz, 2020).

Nick Marro, kepala badan analisis di Economist Intelligence Unit bahkan memprediksi bahwa pembatasan Foreign Direct Investment dari 
negara - negara akibat sentimen anti-Tiongkok yang muncul karena anggapan negatif mengenai penanganan virus korona akan mengakibatkan turunnya investasi asing Tiongkok sebesar 30\% yang merupakan sesuatu yang berbahaya terhadap rencana Belt Road Initiative (Elmer, 2020).

Walaupun persentasenya minim dalam dana yang digunakan untuk BRI yaitu hanya sebesar 20 - 30\%, namun kecilnya uang yang dikeluarkan oleh para pengusaha juga menjadi salah satu permasalahan dalam keberlangsungan proyek BRI ini. Besarnya dana yang dibutuhkan dalam melakukan proyek ini mengakibatkan Presiden Xi Jinping kemudian mengeluarkan proyek - proyek peminjaman dana terhadap pihak swasta dengan nilai 250 miliar Yuan dan 130 miliar Yuan dalam usaha mendukung proyek BRI. Namun, munculnya pandemi mengakibatkan bergesernya pengeluaran dari para pengusaha yang kemudian menggeser pengeluarannya ke bidang lain di luar BRI, selain itu sinophobia juga mengakibatkan beberapa pengusaha yang ada di dunia kemudian enggan melakukan investasi dalam proyek ini, karena sentimen negatif negara asal mereka serta rasa percaya yang rendah terhadap pemerintah Tiongkok.

\section{Kesimpulan}

Neoliberalisme ekonomi merupakan pemikiran yang berfokus pada pembebasan pasar dan menghilangkan, atau mengurangi, campur tangan pemerintah dalam perekonomian dunia. Dengan menggunakan pandangan tersebut, artikel ini mempelajari kebijakan Peaceful Rise Cina. Selain itu pula, dengan menggunakan kejadian-kejadian terkini, artikel ini mempelajari pengaruh dari kejadian-kejadian tersebut dalam perkembangan dan kesuksesan Peaceful Rise Cina. Kebijakan Peaceful Rise sendiri merupakan usaha Cina dalam membuka membebaskan pasarnya, yang mana perusahaan-perusahaan domestik Cina kebanyakan 
di bawah kontrol negara. Melihat bagaimana hal ini bertentangan dengan definisi singkat Neoliberalisme, definisi lanjutan neoliberalisme juga digunakan. Definisi tersebut menyatakan bahwa campur tangan pemerintah tidak akan peran bisa dipisahkan dari pasar, yang merupakan definisi yang baik digunakan untuk pembelajaran kasus kebijakan Peaceful Rise. Dalam konklusi, Kebijakan Peaceful Rise Cina merupakan contoh praktik proses neoliberalisasi ekonomi oleh Cina dalam dunia nyata, yang mana kebijakan tersebut memerlukan kebijakan-kebijakan pemerintah untuk dapat menciptakan pasar yang terbuka dan efisien, menambahi hal tersebut, COVID-19 berpengaruh terhadap Peaceful Rise dengan menghambat proses terjadinya Belt Road Initiative hal ini dipengaruhi oleh faktor-faktor seperti alokasi dana, berkurangnya investasi, serta berkurangnya tenaga kerja secara keseluruhan.

\section{DAFTAR PUSTAKA}

AIIB. (2017, September 30). About AIIB Overview - AIIB. Retrieved from www.aiib.org: https://www.aiib.org/en/about-aiib/index.html

Balaam, D. N., \& Dillman, B. (2013). Introduction to International Political Economy. Routledge.

Chen, D. (2014, Juni 12). Does China Care About its International Image? Retrieved from The Diplomat: https:/ / thediplomat.com/2014/06/does-china-care-about-itsinternational-image /

Chinese State Council. (2005, December 22). Full Text: China's Peaceful Development Road. Retrieved from People's Daily Online: http: / / en.people.cn/200512/22/eng20051222_230059.html

Elmer, K. (2020, April 25). Coronavirus: China's belt and road plan may take a year to recover from slower trade, falling investment. Retrieved from South China Morning Post: https://www.scmp.com/news/china/diplomacy/article/3081267/cor onavirus-chinas-belt-and-road-plan-may-take-year-recover

Heywood, A. (2013). Global Politics. Macmillan International Higher Education. 
Hobson, J. M. (2004). The Eastern Origins of Western Civilization. Cambridge: Cambridge University Press.

Kumar, A. (2012). New Security Concept of China: An Analysis. New Delhi: Institute of Peace and Conflict Studies.

Lamy, S. L., Masker, J. S., Baylis, J., Owens, P., \& Smith, S. (2014). Introduction to Global Politics. Oxford University Press.

Mingst, K. A., \& Arreguin-Toft, I. M. (2017). Essentials of International Relations (7th ed.). W. W. Norton \& Company.

Oxford Business Group. (2020, April 20). How will the international Covid19 outbreak impact the Belt and Road Initiative? Retrieved from Oxford Business Group: https://oxfordbusinessgroup.com/news/how-willinternational-covid-19-outbreak-impact-belt-and-road-initiative

Putz, C. (2020, Februari 20). Kyrgyz-Chinese Joint Venture Scrapped After Protests. Retrieved from The Diplomat: https: / thediplomat.com/2020/02/kyrgyz-chinese-joint-venturescrapped-after-protests /

Ramasamy, B., Yeung, M., Utoktham, C., \& Duval, Y. (2017). Trade and trade facilitation along the Belt and Road Initiative corridors. ARTNeT Working Paper Series, Bangkok, ESCAP (172).

Suettinger, R. L. (2004). The Rise and Descent of "Peaceful Rise". China Leadership Monitor, 12(2), 1-10.

Sujian, G. (2006). Introduction: Challenges and Opprtunities for China's "Peaceful Rise". In G. Sujian (Ed.), China's Peaceful Rise in the 21st Century: Domestic and International Conditions (pp. 1-16). Hampshire \& Burlington: Ashgate Publishing.

Suzana Sawyer, E. T. (2012). The Politics of Resource Extraction: Indigenous People, Multinational Corporations, and the State. Palgrave Macmillan.

Xinhua. (2015, Maret 28). Chronology of China's Belt and Road Initiative. Retrieved from The State Council of the People's Republic of China: http://english.www.gov.cn/news/top_news/2015/04/20/content_28 1475092566326.htm 